成している。5 時間後の回折像走示（写真 5 )。

以上の実験で, 室温で姑結晶化し李加存 CuS, CdS の皮膜は, 温度を上げるととにより容易に結晶化す7と

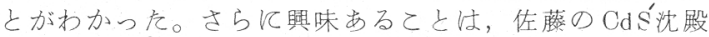
生成の実験 ${ }^{3)}$ で陰イオンが $\mathrm{SO}_{4}^{=}$のとは立方型 $\mathrm{Cd}$ Sが生 成するにもかかわらず，ZnSが下地飞ある場合怡六方型 CdSの結晶が生長するととである。

以上の結果加 ，硫化物之重金属塩の作用飞よって生 じた活性化生成物の構造は, 試料の性質, 溶液の性質末 よび測定手段によって異なった結果を得るので総合的な 研究が必要である。

$$
\text { 文献 }
$$

1) R. Sato: J. Phys. Soc. Japan, $\underline{8}, 152$ (1953) ; $\underline{8}, 454$
(1953)

任藤亮一郎：日鉣誌， 70，63 (1954)；70，359（1954） 70, 415 (1954)

佐藤亮一郎：応用物理， 24,413 (1955)

R. Sato: "Proc. 2nd Intern. Congr. Surface Activity, Vol.3", p. 349 (1957) Butterworths.

R. Sato: Nature, 184, 2005 (1960) ; Acta.Cryst., 15, 1109 (1962)

2) S. R. B. Cook: "Advances in Colloid Science, Vol. 3", p. $321 \sim 374$ (1950), Interscience

3) R. Sato, H. Itoh and S. Yamashita: Japan. J. Appl. Pbys., 3, 626 (1964)

\title{
2313 方鉛鉱へのクロム酸，炭酸イオンの作用に関する電子線回折的研究
}

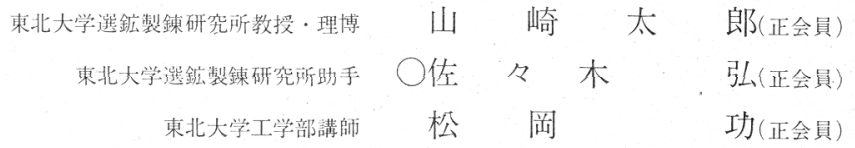

\section{1. 緒袞}

浮選現象の解明飞電子線回折在応用した例は,わが国 の萩原 ${ }^{1}$ ， 佐藤 ${ }^{2}$ 両氏のすぐれた研究があり，前者注

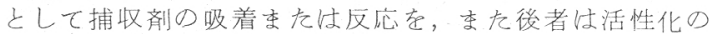
問題在取扱っている。

万鉛鉱に対するザンセートあるいはエロフロートの吸 着関しては, 萩原が表面酸化の程度により吸着状態の 異なるとと老述べている。

われわれは方鉛鉣へ主開面に対して, 夕口ム酸, 炭酸 イオンの作用在電子線回折により研究するとと老試みた。 方鉛鉣飞対する抑制作用忙 $\mathrm{Pb}^{2+}$ と一般飞不溶性沈段在つ くるアニオン $\left(\mathrm{CrO}_{4}^{=}, \mathrm{Cr}_{2} \mathrm{O}_{7}^{=}, \mathrm{PO}_{4}^{=}\right.$, 支ど)あるいは錯イオ ン在形成するアニオン $\left(\mathrm{S}_{2} \mathrm{O}_{3}\right.$ 存ど) があるがその作用 機構估十分《伎明らか飞されてい劣い上5である。今回 は, クロム酸イオン, 炭酸イオンがエロフロートを捕収 剂に用いた場合，方欽鉣の気泡付着にどの上ら索影響圭

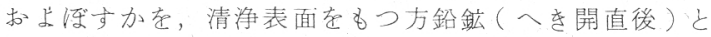
酸化皮膜在有与る方鉛鉱について比較した乎のにつき述 ベる。

\section{2. 試料および実䮶方法}

方鉛鉣は大泉鉱山産単結晶で実験前に $2 \mathrm{~mm} \times 2 \mathrm{~mm} \times 1 \mathrm{~mm}$ ぐららのへさ開試料老つくらた。清浄表面をもった試料 はへき開面そのものとした。酸化皮膜在もった試料は萩

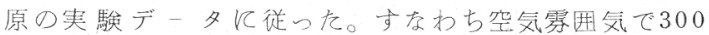
${ }^{\circ} \mathrm{C}, 10$ 分酸化させた。抑制剂は夕口ム酸力りウムと炭酸
ナトリウムの市販特級品走その李用いた。捕収剂は常 法で作製したブチルエロフロートのカリウム塩在用いた。 $\mathrm{pH}$ 調節は $\mathrm{HNO}_{3}$ と $\mathrm{NaOH}$ で祘と索い, すべてイオン強度 0.1 《なるよ 5 ね $\mathrm{KNO}_{3}$ で調整した。

実験壮所定溶液 $100 \mathrm{~m} /$ 中に数個の試料走投入し, 25 ${ }^{\circ} \mathrm{C}$ 恒温槽中で放置し，一定時間後に試料怘取り出し，水 洗して直ちに電子線回折室に入れた。水中からすくん上 げて写真撮影李でに要する時間は約 20 分である。

電子線回折牥前報と同じで，反射回折像走撮る。

\section{3. 実 験 結 果}

空気中で加熱した試料は写真 $10 よ 5 に \mathrm{PbSO}_{4}$ 专生成 し萩原の結果之同じ傾向である。との酸化皮膜は水中で 容易反溶解する。

\section{1 $0.2 \mathrm{M} \mathrm{Na}_{2} \mathrm{CO}_{3} ， \mathrm{~K}_{2} \mathrm{CrO}_{4}$ 溶液中での作用}

酸化 $\mathrm{PbS}^{\prime}$ V $0.2 \mathrm{M}$ の $\mathrm{K}_{2} \mathrm{CrO}_{4}, \mathrm{Na}_{2} \mathrm{CO}_{3}$ 溶液を作用させる

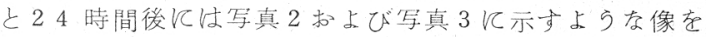
得灰。 $\mathrm{CrO}_{4}^{-}$の作用に上って $\mathrm{PbCrO}_{4}$ の生成がみられる。 $\mathrm{PbCrO}_{4}$ 壮微少古多結晶の集合体である。一方 $\mathrm{CO}_{3}^{=}$の作 用した面怡鉛の炭酸塩と思われるものが力向性をもって 単結晶成長している。一方清净表面 $\mathrm{PbS} V 0.2 \mathrm{M} \mathrm{Na} \mathrm{CO}_{3}$ 水溶液走作用させると, 数日後に和て子酸化 $\mathrm{PbS}$ の場 合の様な別種の結晶成長はみられなかった。す质わち， やや海けた $\mathrm{PbS}$ 像が得られるのみであった。20日後 では写真 4 亿示与上与な像に変化する。従的て $\mathrm{CrO}_{4}^{=}$， $\mathrm{CO}_{3}^{=}$は $\mathrm{PbS}$ 表面酸化によってそれらの塩が生成される ととがわかる。

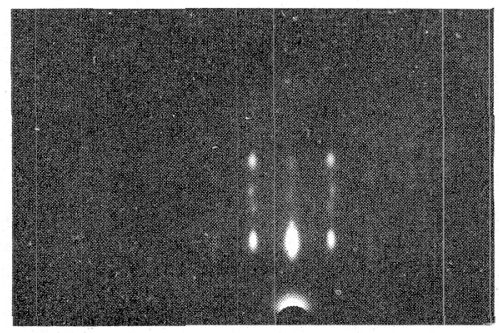

写真 1 酸化老受けた $\mathrm{Pb}_{\mathrm{b}} \mathrm{S}$

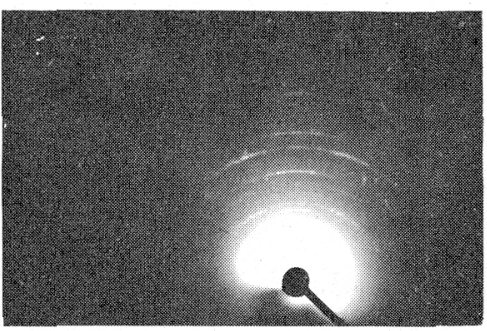

写真2 酸化 $\mathrm{P}_{\mathrm{b}} \mathrm{S} \mathrm{KK}_{2} \mathrm{CrO}_{4}$ 老作用

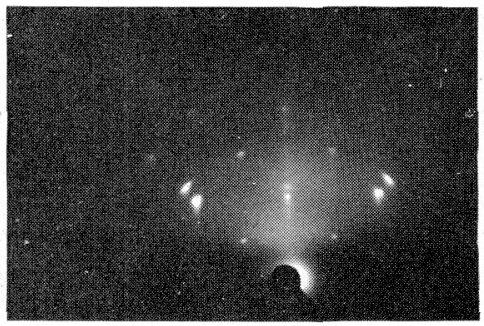

写真 3 酸化 $\mathrm{PbS} K \mathrm{Na}_{2} \mathrm{CO}_{3}$ 老作用 
3・2 ブチルエロフロートとの作用

清净 $\mathrm{PbS}$, 酸化 $\mathrm{PbS}$ のいずれも，1 $100 \mathrm{M}$ ブチルエ上 フロートによって踈水性老示すが, それらの回折像はい ずれもPbSの縞模様がやや你ける程度であり, 吸着状態 の判定恃困難である。

3・3 $\mathrm{CrO}_{4}^{=}, \mathrm{CO}_{3}^{=}$とエロフロートとの混合作用

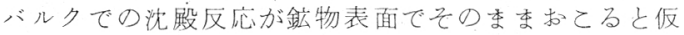
定すれば，エロフロート， $\mathrm{CrO}_{4}^{=}, \mathrm{CO}_{3}^{=}$支り鉛塩の溶解 度が浮選老支配するので, それぞれの溶解度曲線を $\mathrm{pH}$ の関数としてグラフ化しておくと便利である(図略)。 らずれもアルカリ側で，クロム酸鉛，炭酸鉛がエロフロ 一ト鉛より溶解度が小さく支るととがある。そとで沈殿 反応としては抑制条件飞溶液索䦚合する。

A. $\mathrm{CrO}_{4}^{=}$ーブチルエロフロート(BuAf) 系

全 $\mathrm{CrO}_{4}^{=}=10^{-2}$, 全 $\mathrm{BuAf}=10^{-3}$ で $\mathrm{pH}=7.5$ ， イオ

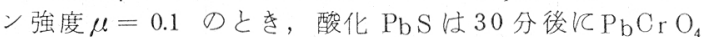
の生成による回折像が見られる。表面怡親水性で気泡に 付着しない。清净 PbS では写真 5 亿示すよらに下地の

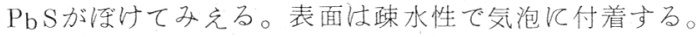
しかしこの表面は時間とともに変化在和とす。

B. $\mathrm{CO}_{3}^{=}-\mathrm{BuAf}$ 采

全 $\mathrm{CO}_{3}^{-}=10^{-2}$, 全 $\mathrm{BuAf}=10^{-3}, \mathrm{KNO}_{3}$ と $\mathrm{NaOH}$ で

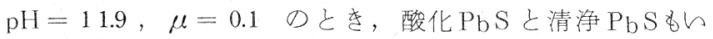
ずれも下地の $\mathrm{PbS}$ の像の现現れる。酸化皮膜走厚くする とデバイ環が現れるが何にもとづくのか不明である。清 浄 $\mathrm{PbS}$ 場合壮気泡江付着する。

以上 2,3 の実験結果加 $\mathrm{CrO}_{4}^{=}, \mathrm{CO}_{3}^{=}$は $\mathrm{PbS}$ の表面 が酸化されていると，その表面にそれらの塩在形成する ことが電子線回折により認められた。东た酸化 $\mathrm{PbS}$ 清 浄 $\mathrm{PbS}$ 亿比べて抑制され易的と考えられる。

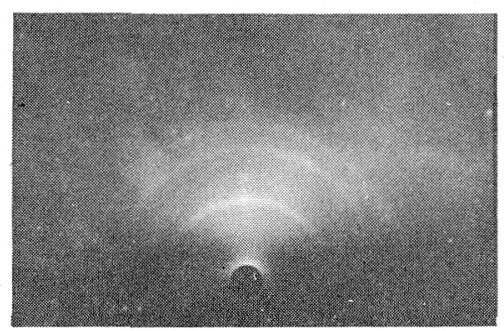

写真4 清浄 $\mathrm{PbS}$ 知 $\mathrm{Na}_{2} \mathrm{CO}_{3}$ 老 20 日間作用

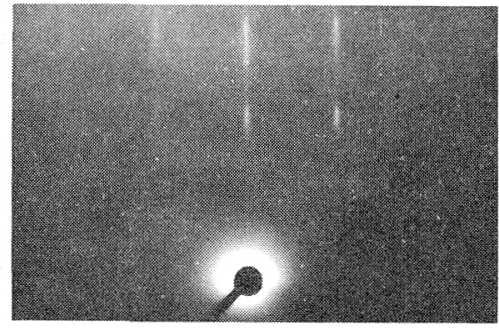

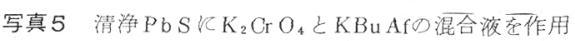

文献

1) H. Hagihara: J. Phys. Chem, 56, 610 (1952), $\underline{56}, 616$ (1952)

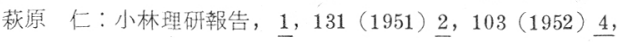
30 (1954)

H. Hagihara, H. Uchikoshi,S. Yamashita: "Proc. 2nd Intern. Congr. Surface Activity, Vol.3” p. 343 (1957), But terworths. 2) 前報の文献1）に同し

\section{.2314 北海道大江鉱山産菱マンガン鉱と重晶石の優先浮選について}

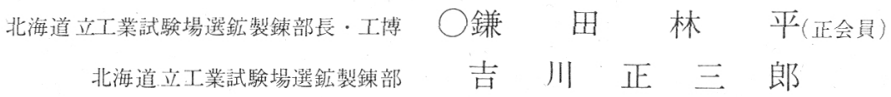

1. 緒言

北海道余市郡仁木町大字然別の北進鈗業大江鉱業所で 恰金, 銀, 黄銅鉣, 黄鉄鉣, 方鉛鉱, 閃严鉛鉱, 菱マン ガン鉱索ど多種類の有用鉣物を産出する你か, 重晶石を も含有している。選鉱場ではこの複雑存鉱石をオールス ライム優先浮選法氏よって鉛, 金, 銀, 銅, 曹鉛, 硫化 鉄, マンガンと順次回收しているが共生する重晶石は回 收でさず現在の処放裹している。乙の重晶石牥鋶飞対 して約 $4 \%$ 含有しているので月間 8,000 拠理之して約 $320 \mathrm{t}$ 選鉱工程に入ってくるのでこれ老回收しボーリン グ* その他の用に供せんとするのが本研究の目的である。

\section{2. 試験試料について}

第 1 図滨鉱場のフローシートを示す。

第 1 図フローシートによって試料が試験前にどのような 工程を経ているか理解でをる。試料採取は 56 脱バライト 浮選のフロス(C)である。現場から送られたものにつんて 粒度分布試験, 化学分析を行なった結果は第 1 表の上 5 であった。

*ボーリング用としては比重 4.2 以上 $\mathrm{BaSO}_{4}$ として $92 \%$ 以上の品位 老必要与する。
第 1 表 試料の粒度分布示よび品位

\begin{tabular}{|c|c|c|c|c|}
\hline \multirow{2}{*}{$\begin{array}{c}\text { 鉝石粒度 } \\
\mathrm{mm}\end{array}$} & \multirow{2}{*}{$\begin{array}{r}\text { 分布率 } \\
\%\end{array}$} & \multicolumn{2}{|c|}{ 品 } & $\%$ \\
\hline & & $\mathrm{Ba} \mathrm{SO}_{4}$ & $\mathrm{SiO}_{2}$ & $\mathrm{Mn}$ \\
\hline+0.088 & 7.54 & 73.76 & 11.92 & 4. 46 \\
\hline$\sim 0.075$ & 2.42 & 81.44 & 7.64 & 3.10 \\
\hline$\sim 0.044$ & 17.95 & 79.50 & 3.64 & 5.15 \\
\hline-0.044 & 72.09 & 64.92 & 1.24 & 11.70 \\
\hline 全 体 & 100 & 68.60 & 2.63 & 9.77 \\
\hline
\end{tabular}

3. 試 験 結 果

フローシートに示すよらに試料は種々の試薬によって 処理された後の浮選であるから新鮮な鉱石の処理之違っ て困難であり歩留りも低い。しかし本試験将步留りを無 視し $\mathrm{BaSO}_{4} 92 \%$ 以上の精鉱在得るとと老目的として行 なったもので一応その目的起達した。

\section{$3 \cdot 1$ 一次浮選試験}

$\mathrm{pH}$ 調節に上りある程度品位を高めることがでをるの ではないかと思い酸に硫酸, 塩酸を,アルカリには水酸 化ナトリウム在使用し $100 \mathrm{~g}$ 浮選試験機によらて試験し

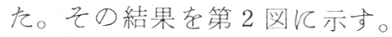

以上により， pH $3.5 \sim 4.0$ で尾鉱側の重晶石の品位が 上ることが判明したのでさられ500 g 浮選試験機に上り 硫酸, 塩酸の効果の此較索した。結果注第3図のよ5で 